\title{
OPEN Author Correction: FMNL2 and -3 regulate Golgi architecture and anterograde transport downstream of Cdc42
}

\section{Frieda Kage, Anika Steffen, Adolf Ellinger, Carmen Ranftler, Christian Gehre, Cord Brakebusch, Margit Pavelka, Theresia Stradal \& Klemens Rottner (i)}

Correction to: Scientific Reports https://doi.org/10.1038/s41598-017-09952-1, published online 29 August 2017

This Article contains an error in the Methods section under the subheading 'DNA-constructs'.

"For EGFP-tagging, the full length sequence was amplified using forward primer $5^{\prime}$-GAGGAATTCAT GGGCAATGCTGCCGG-3' and reverse primer 5'-GAGGGATCCCTAGTGGTGGTGATGATGG-3' harboring a stop codon."

should read:

"For EGFP-tagging, the full length sequence was amplified using forward primer 5'-GAGGAATTCAT GGGCAATGCTGCCGG-3' and reverse primer 5'-GAGGGATCCCTACAGGGGCATTTCCTCGCC-3' harboring a stop codon."

In addition, this Article contains an error in the Results and Discussion section under the subheading 'Cdc42-induced FMNL2/3 accumulation stimulates formin-specific actin filament assembly'.

"Importantly, respective FMNL2 and FMNL3 mutants (FMNL2-I1704A and FMNL3-1649A, respectively) still co-localized with Cdc42, but failed to induce the prominent actin accumulations frequently seen with wildtype FMNL2 or FMNL3 (Fig. 2b)."

should read:

"Importantly, respective FMNL2 and FMNL3 mutants (FMNL2-I704A and FMNL3-I649A, respectively) still co-localized with $\mathrm{Cdc} 42$, but failed to induce the prominent actin accumulations frequently seen with wildtype FMNL2 or FMNL3 (Fig. 2b)."

(c) (i) Open Access This article is licensed under a Creative Commons Attribution 4.0 International License, which permits use, sharing, adaptation, distribution and reproduction in any medium or format, as long as you give appropriate credit to the original author(s) and the source, provide a link to the Creative Commons license, and indicate if changes were made. The images or other third party material in this article are included in the article's Creative Commons license, unless indicated otherwise in a credit line to the material. If material is not included in the article's Creative Commons license and your intended use is not permitted by statutory regulation or exceeds the permitted use, you will need to obtain permission directly from the copyright holder. To view a copy of this license, visit http://creativecommons.org/licenses/by/4.0/.

(c) The Author(s) 2019 